\title{
Statistical Analysis and Interpretation of High-, Mid- and Low-Latitude Responses in Regional Electron Content to Geomagnetic Storms
}

\author{
Konstantin G. Ratovsky ${ }^{1, *}$, Maxim V. Klimenko ${ }^{2}\left(\mathbb{D}\right.$, Yury V. Yasyukevich $^{1, *} \mathbb{1}$, \\ Vladimir V. Klimenko ${ }^{2}$ and Artem M. Vesnin ${ }^{1}$ \\ 1 Institute of Solar-Terrestrial Physics SB RAS, p/o Box 291, 126a Lermontov Str., 664033 Irkutsk, Russia; \\ artem_vesnin@iszf.irk.ru \\ 2 West Department of Pushkov IZMIRAN RAS, 41 Pobedy Avenue, 236017 Kaliningrad, Russia; \\ mvklimenko@wdizmiran.ru (M.V.K.); vvk_48@mail.ru (V.V.K.) \\ * Correspondence: ratovsky@iszf.irk.ru (K.G.R.); yasukevich@iszf.irk.ru (Y.V.Y.)
}

Received: 30 October 2020; Accepted: 30 November 2020; Published: 2 December 2020

\begin{abstract}
Geomagnetic storm is one of the most powerful factors affecting the state of the Earth's ionosphere. Revealing the significance of formation mechanisms for ionospheric storms is still an unresolved problem. The purpose of the study is to obtain a statistical pattern of the response in regional electron content to geomagnetic storms on a global scale to interpret the results using the upper atmosphere model (the Global Self-consistent Model of the Thermosphere, Ionosphere, and Protonosphere), to make the detailed comparison with the thermospheric storm concept, and to compare the obtained pattern with results from previous statistical studies. The regional electron content is calculated based on the global ionospheric maps data, which allows us to cover the midlatitude and high-latitude zones of both hemispheres, as well as the equatorial zone. Most of the obtained statistical pattern agrees with the thermospheric storm concept and with the previous statistical studies: ionospheric responses at ionospheric storm main phases including their seasonal dependences for the high- and midlatitudes and some features of ionospheric responses at recovery phases. However, some of the statistical patterns are inconsistent with the thermospheric storm concept or contradicts the previous statistical studies: negative midlatitude ionospheric responses at recovery phases in the local winter, the domination of the spring response in the equatorial zone, seasonal features of the positive after-effects, the interhemispheric asymmetry of ionospheric responses, and the prestorm enhancement. We obtained that the contribution of electric field to the interpretation of the zonal and diurnal averaged storm-time regional electron content (REC) disturbances is insignificant. The positive after-storm effects at different latitudes are caused by $\mathrm{n}(\mathrm{O})$ disturbances.
\end{abstract}

Keywords: statistics; ionosphere; geomagnetic storm; regional electron content; GSM TIP model

\section{Introduction}

Geomagnetic storm is one of the most powerful factors affecting the state of the Earth's ionosphere. Revealing the significance of formation mechanisms for ionospheric storms is still an unresolved problem. Statistical analysis is one of the methods for studying the ionospheric response to various events, in particular, to geomagnetic storms. As a rule, statistical analysis is implemented through the superposed epoch technique, which is an averaging of ionospheric responses to events of the same type, synchronized with respect to the key time. Unlike case studies, this kind of analysis allows us to smooth out the individual feature of responses to the selected events and to obtain patterns 
characteristic of all responses as a whole. The well-known reviews of geomagnetic storms [1-4] and the review of ionospheric precursors [5] contain data on statistical studies. We will compare the obtained results with the results from [1-5] in Section 5.

In our previous statistical studies of ionospheric response to geomagnetic storms [6,7], we used both local (peak electron density NmF2) and global (global electron content, GEC) characteristics. The disadvantage of using the local characteristic is the large scatter of individual responses relative to the average value (at best, the scatter is comparable to the average value). In the case of using the global electron content, it is impossible to separate the contributions of different latitude zones to the global effect. This study uses the regional electron content $(R E C)$ that is the average value of the total electron content (TEC) for the selected latitude-longitude region. On the one hand, such a choice allows us to reduce the scatter of individual responses relative to the average value; on the other hand, it becomes possible to obtain separate responses of the midlatitude and high-latitude zones of both hemispheres, as well as the response of the equatorial zone.

The regional electron content being the total number of electrons in the region or the regionally averaged TEC has been used in previous studies with averaging over latitude zones in climatological studies [8-10] or over longitudinal sectors in the case study of the ionospheric response to the St. Patrick's Day geomagnetic storm [11]. The annual amplitude of midlatitude REC variations is greater in the Southern hemisphere compared to the Northern one [8,9]. The annual phases of midlatitude REC variations are relatively stable in the Southern Hemisphere and shift toward vernal equinox and even December solstice in the Northern Hemisphere [9]. The semiannual components of midlatitude $R E C$ variations have comparable amplitudes in both hemispheres and demonstrate in-phase modulations [8,9]. The low latitude REC has the highest sensitivity to solar activity $[9,10]$. At high solar activity (F10.7 index in the range of $\sim 150-250 \mathrm{sfu}$ ), the amplitude of semiannual component is two times larger at the equatorial geomagnetic latitudes than at high latitudes [10]. The case study [11] revealed that during the St. Patrick's Day geomagnetic storm, the positive storm effects were observed in all longitudinal sectors excluding the Pacific one, with the strongest positive storm effects in the American sector. The negative storm effects were observed in all longitudinal sectors with the largest negative impact in the Asian sector. The method for calculating the regional electron content used in this study is described in Section 2.

We expect that the statistical pattern of the ionospheric response to geomagnetic storms corresponds mainly to the thermospheric storm concept $[1-4,6,12,13]$. That implies that the thermospheric composition and wind disturbances caused by heating in a high-latitude region are expected to be among the main drivers of the ionospheric response to geomagnetic storm. The storm-induced electric field can also play an important role in the formation of the ionospheric response.

During the main phase of a geomagnetic storm, the auroral thermosphere is heated due to increase in Joule heating by ionospheric currents and enhancement of auroral precipitation. Heating leads to the formation of additional pressure gradient from the pole to the equator and increased neutral density in the upper thermosphere. Due to high-latitude heating and a corresponding increase in the scale heights of all neutral components, the densities of molecular nitrogen $n\left(\mathrm{~N}_{2}\right)$ and atomic oxygen $n(\mathrm{O})$ increase in the upper thermosphere of high latitudes. Excess pressure in the auroral thermosphere changes the wind pattern and a horizontal transfer of air from the auroral region to middle and equatorial latitudes. Atomic oxygen, as a lighter gas, is transported faster and farther away from the heating zone in comparison with molecular nitrogen, as a heavier gas. The electron density increases/decreases with increasing/decreasing the $n(\mathrm{O}) / n\left(\mathrm{~N}_{2}\right)$ ratio. The most negative $n(\mathrm{O}) / n\left(\mathrm{~N}_{2}\right)$ disturbances (storm-time changes in $n(\mathrm{O}) / n\left(\mathrm{~N}_{2}\right)$ relative to undisturbed conditions) are formed directly in the heating zone of (high latitudes). With increasing distance from the heating zone (i.e., from high to low latitudes) during initial and main storm phases, the amplitude of the negative $n(\mathrm{O}) / n\left(\mathrm{~N}_{2}\right)$ disturbance weakens, and at some latitude, the transition from the negative to positive phase of the $n(\mathrm{O}) / n\left(\mathrm{~N}_{2}\right)$ disturbance is possible. This kind of $\mathrm{O} / \mathrm{N} 2$ dependence is confirmed by the Dynamics Explorer 2 satellite measurements [14]. Cai et al. [15] recently found that the $\mathrm{O} / \mathrm{N}_{2}$ disturbance zone can 
propagate to the low latitude and stayed there after the weak geomagnetic disturbance ends $(>10 \mathrm{~h})$, while the polar region $\mathrm{O} / \mathrm{N}_{2}$ already recover. The latitudinal boundary of the negative and positive $n(\mathrm{O}) / n\left(\mathrm{~N}_{2}\right)$ disturbances depends on many factors and is the subject of this paper.

The change in the wind pattern consists in the appearance of additional (relatively undisturbed conditions) wind from the pole to the equator, which weakens the daytime wind and enhances the nighttime wind. In any case, relative to unperturbed conditions, the ionospheric plasma uplifts to the altitudes of a lower recombination rate and, accordingly, chemical losses of electron-ion pairs. This uplifting is the cause of either a positive disturbance or a weakening of the negative disturbance of the electron density. Seasonal changes in the background circulation and neutral composition lead to a seasonal dependence of the ionospheric response to magnetic storms. In winter conditions, the background circulation strongly (compared to other seasons) prevents the transfer of air from the auroral region to middle and equatorial latitudes, which significantly weakens the effect of the negative disturbance of $n(\mathrm{O}) / n\left(\mathrm{~N}_{2}\right)$. In summer conditions, the opposite pattern is observed: the background circulation weakly (compared to other seasons) prevents the storm induced transfer of air. Thus, the most positive electron density disturbances are expected in winter, while the most negative disturbances are expected in summer. An interesting consequence of a thermospheric storm is the so-called after-effects of geomagnetic storms [6]. The meridional neutral particle transport from the auroral region to equatorial latitudes leads to the creation of excess pressure in the equatorial region. This initiates the process of reverse transport of air enriched with atomic oxygen from the equator to higher latitudes, which creates conditions for positive disturbances in electron density.

It is important to note that ionospheric effects from storm time electric field can be comparable to those from storm time thermospheric wind [16-21]. Rishbeth and Garriott showed [22] that the occurrence of the additional eastward/westward electric field leads to the additional electromagnetic drift with poleward/equatorward direction in the plane of the geomagnetic meridian and to the upward/downward plasma transport into the region of lesser/higher chemical loss rate, which leads to the positive/negative effects in the ionospheric $\mathrm{F}$ region electron density at low and middle latitudes. Daytime eastward electric field in the vicinity of the geomagnetic equator produces an increase in the electron density at the Equatorial Ionization Anomaly (EIA) crests, their shift to higher latitudes, and the deepening of the EIA trough at the geomagnetic equator. Mannucci et al. [23] demonstrated that an increase in TEC at middle latitudes is accompanied by the EIA intensification and suggested that this is due to the vertical and horizontal transport of ionospheric plasma. Heelis et al. [24] concluded that an equatorward expansion of the high-latitude convection pattern resulted in the TEC enhancements at middle and low latitudes.

Balan et al. [18] showed that the direct effects of the equatorward neutral wind can be the main driver of positive ionospheric storms at low- and midlatitudes. According to their model results, (1) the prompt penetration eastward electric field (PEEF) on its own is unlikely to produce positive ionospheric storms at low- and midlatitudes; (2) the PEEF can cause positive ionospheric storms only in the presence of an equatorward wind. That is because to produce positive ionospheric storms, the plasma raised to higher than normal altitudes and latitudes by the strong $\mathrm{E} \times \mathrm{B}$ (or PEEF) should not be allowed to get lost by heavy chemical loss at low altitudes; in other words, the downward flow velocity component (along field lines) due to diffusion (or gravity) should be reduced or stopped. An equatorward neutral wind does this and also raises the ionosphere to high altitudes of reduced chemical loss. For these reasons, if a strong eastward penetration occurs in the presence of an adequate equatorward neutral wind, there can be a strong positive ionospheric storm. Ratovsky et al. [25] recently confirmed these results. Considerable debate did not lead to a single point of view about mechanisms of the positive ionospheric storms [26-28]. Tsurutani et al. [28] explained the positive ionospheric storm through a combined action of prompt penetration magnetospheric convection electric fields to low latitudes, equatorward expansion of the affected area of magnetospheric convection to lower latitudes, and neutral wind disturbances. Dmitriev et al. [29] and Klimenko et al. [20] showed that the prompt penetration of eastward electric field dominates in producing of the low-latitude positive 
ionospheric storm only $1-2 \mathrm{~h}$ after the storm onset; equatorward neutral wind dominates during the main storm phase and several (2-4) hours afterwards; during the recovery phase and after storm the neutral composition changes play the most important role in the daytime electron density increase at different latitudes. Despite the fact that the electric field effects are important, no one has considered the importance of taking into account electric fields when interpreting the zonal and diurnal averaged ionospheric responses to geomagnetic storms.

One of the most effective ways to interpret storm-time ionospheric disturbances is to use the results of first principles models. A large number of works have been devoted to the numerical modeling of ionospheric storm effects (see, e.g., the review [1]). Numerical modeling showed that: negative ionospheric storms at high latitudes are caused by the formation of the $\mathrm{N}_{2}$ thermospheric bulge [30-32]; compositional perturbations following the onset of the storm were found to propagate to midlatitudes due to the advective effects of equatorward winds [33]; subauroral, mid- and low-latitude positive ionospheric storm are formed by the meridional component of the thermospheric wind [29,31,34]; at low and middle latitudes the positive long-lasting storm-time and after-storm electron density disturbances can be formed in the daytime due to an increase in $n(\mathrm{O}) / n\left(\mathrm{~N}_{2}\right)$ ratio $[6,12,13,20,35-38]$. Balan et al. [34] showed that (1) the storm-time eastward electric field on its own is unlikely to produce positive ionospheric storms at low- and midlatitudes; (2) the storm-time eastward electric field can cause positive ionospheric storms only in the presence of an equatorward wind. Modeling of the seasonal effects of ionospheric response to geomagnetic storms [36] showed that the observed at middle latitudes negative ionospheric storm in summer and positive storm in winter can be explained by the corresponding variations in the thermospheric composition. Three numerical simulations [39] showed that the main seasonal effect was in the prevailing summer-to-winter circulation transports the composition bulge from the summer polar regions to mid and low latitudes, while in winter, the composition bulge was constrained to remain at high latitudes by the flow from the summer hemisphere.

Our study has the following objectives: (1) obtaining the statistical pattern of the REC response to geomagnetic storms for different latitudes; (2) interpreting the obtained results with using the upper atmosphere model; (3) comparing the obtained results with the thermospheric storm concept; (4) discussing the importance of storm-time electric field disturbances for interpretation of statistical pattern of the REC response to geomagnetic storms for different latitudes; and (5) intercomparing with previous statistical studies to verify the obtained statistical pattern and reveal new features of the ionospheric response to geomagnetic storms.

\section{Methods}

\subsection{Statistical Analysis Method}

We used REC as the ionospheric characteristic. The initial data for REC calculation are the global ionospheric maps (GIM) produced by the laboratories included in the IGS consortium [40]. The GIM provides the TEC values for a given year, day of year (DoY), and Universal Time (UT) on the latitude-longitude grid in the geographic coordinate system. In this study, REC is the weighted average of TEC for the selected latitude-longitude region.

We used GIM calculated by the Center for Orbit Determination in Europe (CODE) [41]. CODE algorithm involves spherical harmonics and solar-geomagnetic reference frame. That allows them to also obtain data over oceans. The CODE GNSS network is rather uniform [42]: highest density is in the Europe, lower density is in the Pacific Ocean and in the Southern hemisphere. Roma-Dollase et al. [43] showed that "among the expected degradation at low latitude, in coincidence with the equatorial anomaly peaks, some GIMs degrades significantly at the Southern Hemisphere" but not the CODE GIM (see figures 7 and 8 in [43]). Spatial distribution of error [43] shows that we could expect higher error for the high-latitudes.

For REC calculations, we selected five latitude zones in the corrected geomagnetic coordinate system [44]: the midlatitude zones in both hemispheres, the high-latitude zones in both hemispheres, 
and the equatorial zone. Spatiotemporal ranges for REC calculation (averaging of TEC) are presented in Table 1. As a result, we have the REC values for the five latitude zones as functions of Year and DoY.

Table 1. Spatiotemporal ranges for regional electron content $(R E C)$ calculation in corrected geomagnetic coordinates.

\begin{tabular}{|c|c|c|c|}
\hline Region & Latitude Range & Longitude Range & UT Range \\
\hline Northern Hemisphere high-latitude zone & $60 \div 90^{\circ}$ & $0 \div 360^{\circ}$ & $0 \div 24$ \\
\hline Northern Hemisphere midlatitude zone & $30 \div 60^{\circ}$ & $0 \div 360^{\circ}$ & $0 \div 24$ \\
\hline Equatorial zone & $\pm 30^{\circ}$ & $0 \div 360^{\circ}$ & $0 \div 24$ \\
\hline Southern Hemisphere midlatitude zone & $-30 \div-60^{\circ}$ & $0 \div 360^{\circ}$ & $0 \div 24$ \\
\hline Southern Hemisphere high-latitude zone & $-60 \div-90^{\circ}$ & $0 \div 360^{\circ}$ & $0 \div 24$ \\
\hline
\end{tabular}

The error of vertical TEC for each GIM cell is about 10-20\% [41]. The GEC/REC error is $\sim / \sqrt{ } \mathrm{n}$ [45] (implying that $\sigma$ is the same for all GIM cells and time instances, and all cells are independent), where $\sigma$ is a TEC error for a GIM cell, and $n$ is a number of cells. Astafyeva et al. [45] showed that GEC relative error (for one time instance) is $\sim 0.3 \%$. Actually, the error is a little higher due to interdependence of TEC in different GIM cells. For midlatitude REC (864 cells, 12 time instance), the error is $\sim 0.2 \%$ if TEC error is $\sim 20 \%$. The TEC errors $\sim 25-50 \%$ at Northern high-latitudes and $\sim 35-70 \%$ TEC at Southern high-latitudes [43] result in up to $\sim 0.5 \%$ and $\sim 0.7 \%$ REC error, correspondingly.

For calculating the $R E C$ disturbances, we used the 27 -day running mean of $R E C\left(R E C_{\text {mean }}\right)$ as a reference level:

$$
R E C_{\text {mean }}(\text { Year }, \text { DoY })=\sum_{D=D o Y-13}^{D=D o Y+13} \operatorname{REC}(\text { Year }, D)
$$

The ionospheric disturbances are the percentage deviations of $R E C$ from $R E C_{\text {mean }}$ :

$$
\Delta R E C(Y e a r, D o Y)=\frac{R E C(Y e a r, D o Y)-R E C_{\text {mean }}\left(Y_{\text {ear }}, \text { DoY }\right)}{R E C_{\text {mean }}(\text { Year }, \text { DoY })} \cdot 100 \%
$$

In further statistical analysis, the $\triangle R E C$ dataset for 1999-2017 was used.

The selection of the Dst index as an index of geomagnetic magnetic activity is based on the geomagnetic storm definition [46] and the classification of geomagnetic storm intensities [46,47]. To implement the superposed epoch technique, we made a list of 1999-2017 geomagnetic storms. We applied three criteria based on the geomagnetic index Dst to qualify events as geomagnetic storms. (1) Dst(Tstorm) is a local minimum (Tstorm is a time point corresponding to the local minimum). (2) Dst(Tstorm) is the lowest Dst value for the interval of Tstorm $\pm 12 \mathrm{~h}$. (3) Dst(Tstorm) is less than or equal to $-50 \mathrm{nT}$. The point in time, Tstorm, is the ending of the main phase and the beginning of the recovery phase of geomagnetic storm. The days corresponding to Tstorm were used as the key times for implementing the superposed epoch technique. Hereinafter, the key time is referred as Day 0 , and statistical analysis is carried out in the interval of days that includes Day 0, five previous days, and five subsequent days.

Our previous experience [6,7] has shown that it is useful to select isolated and strong storms from the entire list of storms. The isolated storms are events separated by the interval equal to or greater than five days. The strong storms are events for which Dst(Tstorm) is less than or equal to $-100 \mathrm{nT}$. This paper presents statistics for isolated and strong storms, since it is these types of storms that are more informative in comparison with the cases of nonisolated and weak magnetic storms $[6,7]$. To reveal the seasonal dependence of the ionospheric response, the geomagnetic storms were split on four seasons. In this study, the seasons (winter, summer, spring, autumn) are 91 -day intervals centered around the winter and summer solstices and the spring and autumn equinoxes in the Northern Hemisphere. Table 2 shows the beginnings and ends of the seasons as well as numbers of isolated and strong storms. Note that isolated storms are mainly weak (only 20 storms of 141 are strong) while strong storms are mainly nonisolated (only 20 storms of 94 are isolated). 
Finally, the statistical analysis was implemented by the following algorithm. Ionospheric responses were divided into cells in line with the latitude zone, storm type, season and the storm day relative to Day 0 (Day $-5, \ldots$, Day 5). For each cell, we calculated the mean value of the $\triangle R E C(\langle\triangle R E C\rangle)$ as well as the standard deviation of $\triangle R E C(\sigma R E C)$. Ratovsky et al. [7] showed that for the interpretation of ionospheric responses to geomagnetic storms, it is necessary to consider influence of solar activity. For this reason, according to the algorithm described above, we performed the calculations of $\langle\triangle F 10.7$ > and $\sigma F 10.7$ for the solar activity index F10.7.

Table 2. Beginnings and ends of the seasons and numbers of storms per season.

\begin{tabular}{ccccc}
\hline Season & Dates & Days of Year & Number of Isolated Storms & Number of Strong Storms \\
\hline Winter & 07 November-22 December-05 February & $311-356-036$ & 15 & 32 \\
Spring & 06 February-22 March-07 May & $037-081-127$ & 17 & 40 \\
Summer & 08 May-22 June-07 August & $128-173-219$ & 20 & 31 \\
Autumn & 08 August-22September-06 November & $220-265-310$ & 42 & 38 \\
\hline
\end{tabular}

To analyze the seasonal variations in geomagnetic storms, we calculated the averaged $D s t$ indices using the same technique as for $\triangle R E C$ and $\triangle F 10.7$. The results are shown in Figure 1. As seen from Figure 1, the averaged Dst behavior is generally similar for all seasons. In the case of strong storms, the amplitude of the minimal Dst on Day 0 is higher than that in the isolated storm case. For isolated storms, the Dst behaviors for different seasons are closer to one another than those in the strong storms case. The insignificance of the seasonal dependence of the averaged Dst index suggests that the contribution of seasonal variations of geomagnetic storms to the seasonal dependence of $\triangle R E C$ response is small.
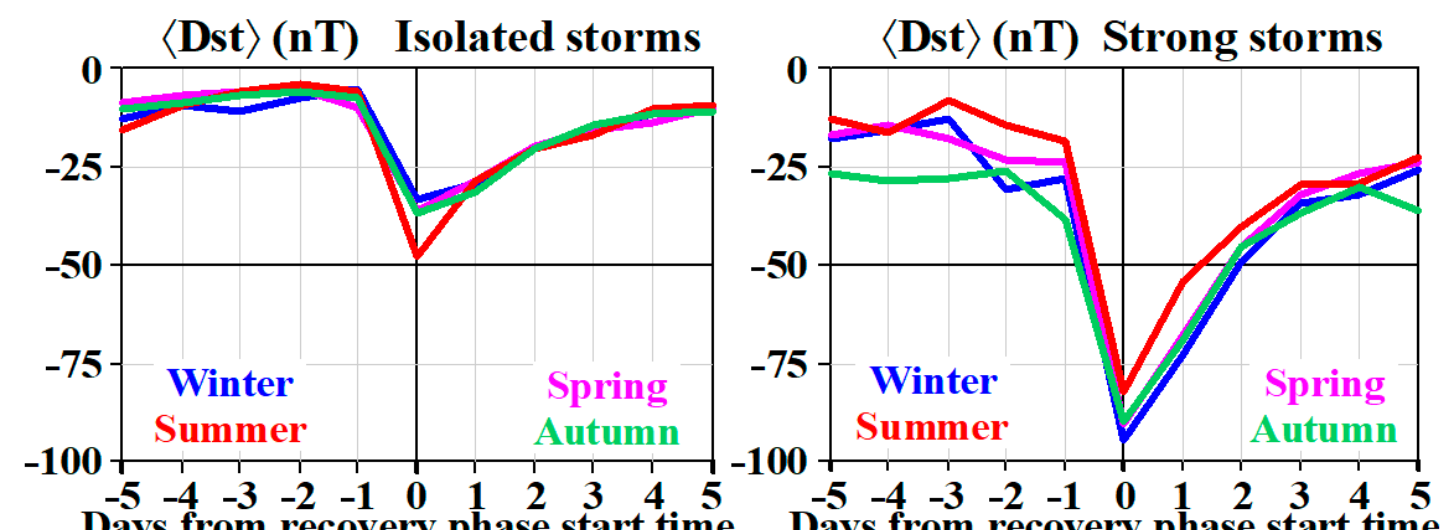

Figure 1. Averaged Dst index as function of day from beginning of geomagnetic storm recovery phase for isolated (left panel) and strong (right panel) storms.

\subsection{Brief Description of Upper Atmosphere Model for Interpretation}

To interpret some results of the statistical analysis of REC response to geomagnetic storms, we use the simulation results. The Global Self-consistent Model of the Thermosphere, Ionosphere, and Protonosphere (GSM TIP) is the first principles upper atmosphere model including electric field simulation. The GSM TIP model was developed in the WD IZMIRAN (West Department of Pushkov Institute of Terrestrial Magnetism, Ionosphere, and Radio wave propagation of the Russian Academy of Sciences) [48,49]. GSM TIP consists of three main modules describing the thermosphere, ionosphere, and electric fields. In the thermospheric module, global distributions of the neutral gas temperature, three-dimensional neutral winds, $\mathrm{N}_{2}, \mathrm{O}_{2}, \mathrm{O}, \mathrm{NO}, \mathrm{N}\left({ }^{4} \mathrm{~S}\right)$, and $\mathrm{N}\left({ }^{2} \mathrm{D}\right)$ are calculated from $80 \mathrm{~km}$ to $526 \mathrm{~km}$ layer using a spherical geomagnetic coordinate system. In the vertical dimension, the thermospheric block has 30 levels, and the horizontal resolution is $5^{\circ} \times 5^{\circ}$. The ionospheric module calculates the three-dimensional density of molecular $\left(\mathrm{N}_{2}{ }^{+}, \mathrm{O}_{2}{ }^{+}, \mathrm{NO}^{+}\right)$, and atomic $\left(\mathrm{O}^{+}, \mathrm{H}^{+}\right)$ions 
and electrons, temperature, and velocities of ions and electrons in E, F2 region, and protonosphere, Additionally, the model provides the two-dimensional electric field potential distribution accounting for the ionospheric dynamo and magnetospheric convection electric fields [50].

For the simulation of the neutral temperature variability during quiet and storm-time condition, the GSM TIP model includes the following terms in thermal balance equations: (1) the work of compression and expansion of neutral gas; (2) convective heating; (3) Joule heating; (4) thermal conductivity; (5) heating by solar radiation; (6) cooling due to infrared radiation of atomic oxygen; (7) heating by precipitating particles; (8) viscous heating. Thus, the GSM TIP can reproduce the storm induced thermospheric heating caused by the strengthening of the high-latitude ionospheric electric fields, currents, and auroral particle precipitation. This heating leads to the appearance of additional storm-time equatorward neutral wind and thermospheric composition redistribution.

To describe the storm-time upper atmosphere, we continuously used the general statement of the problem described in detail in the study [51]. The input parameters for the GSM TIP model runs are: the cross-polar cap electric potential (CPCP) depending on the auroral electrojet index (AE index) according to the parameterization describe in the study [52] and the magnitude of Region 2 Field-Aligned Currents (R2 FAC) according to the study [53]. The R2 FACs are shifted equatorward during geomagnetic disturbances and a 30-min time delay of the R2 FAC variations with respect to the CPCP variations [54] is used. Expansion and contraction of the polar cap and the observed clockwise rotation of the convection pattern are not taken into account in the GSM TIP model [21]. The model adopts the empirical model [55] for high-energy particle precipitation.

Recently, the GSM TIP model was used for interpretation of different aspects of the upper atmosphere response to the 2011 September storm [37,38] and the 2015St. Patrick's Day storm [6,20,21,29]. These studies revealed the essential role of the following factors in the formation of the long-lasting $F$ region ionospheric disturbances: (1) the thermospheric wind enhancement $1-3 \mathrm{~h}$ after the storm onset; and (2) the changes in the atmospheric composition at the later stage of the storm. The after-storm daytime positive disturbances in $\mathrm{F}$ region electron density at different latitudes were reveled and explained by an increase in $\mathrm{O} / \mathrm{N}_{2}$ ratio $[6,20,37,38]$. The obtained tongue-like structure in the molecular nitrogen concentration and storm-time neutral wind disturbances play an important role in the formation of the tongue of ionization structure in the ionospheric F region [21]. The GSM TIP model reproduces temporal evolution of the main high-latitude ionospheric structures (such as tongue of ionization, main ionospheric trough) during the storm time $[20,21]$.

\section{Statistical Analysis Results}

We start presenting statistical results with the midlatitude zone to establish a standard of analysis that will then be used for other latitudinal zones. The analyzed interval of ionospheric responses ( \pm 5 days from the beginning of the geomagnetic storm recovery phase) is divided into three phases. These are the prestorm phase (Days $-5 \div-1$ ), the main phase of ionospheric storm (Days $0 \div 1$ ) (not to be confused with the main phase of geomagnetic storm) and the recovery phase of ionospheric storm (Days $2 \div 5$ ) (here we have a complete analog with the recovery phase of geomagnetic storm). Hereinafter, the terms of the local winter (22 Dec \pm 45 days in the Northern Hemisphere and 22 Jun \pm 45 days in the Southern one) and the local summer (22 Jun \pm 45 days in the Northern Hemisphere and $22 \mathrm{Dec} \pm 45$ days in the Southern one) will be used. In Section 3, we explain the REC effects based on a thermospheric storm concept excluding the effects of electric fields. The reasons for this approach will be presented in Sections 4 and 5.

\subsection{Midlatitude Zone}

Figure 2 shows the average response in $\triangle R E C(\langle\triangle R E C\rangle)$ as a function of day from the beginning of the geomagnetic storm recovery phase for the midlatitude zones of both hemispheres.

At main phases of ionospheric storms, one may see both the largest positive response on Day 0 for the local winter and the largest negative response on Day 1 for the local summer. The spring and 
autumn responses are always intermediate between the local winter (most positive) and local summer (most negative) responses. The more negative response on Day 1 compared to Day 0 is explained by the delay in the molecular nitrogen transfer relative to the atomic oxygen transfer and the change in neutral wind. The main difference between the different types of storms is that the negative response for strong storms is noticeably stronger than for isolated storms. This pattern is observed for all seasons on Day 1 and for all seasons except for the local winter on Day 0. Given that isolated storms are mostly weak, this pattern is explained by the stronger molecular nitrogen disturbance in the case of strong storms. For the local winter on Day 0 , the effect of increase in molecular nitrogen competes with the effect of an increase in equatorward wind. This behavior at the main phase of the ionospheric storm agrees well with the thermospheric storm concept including the seasonal dependence of ionospheric responses.
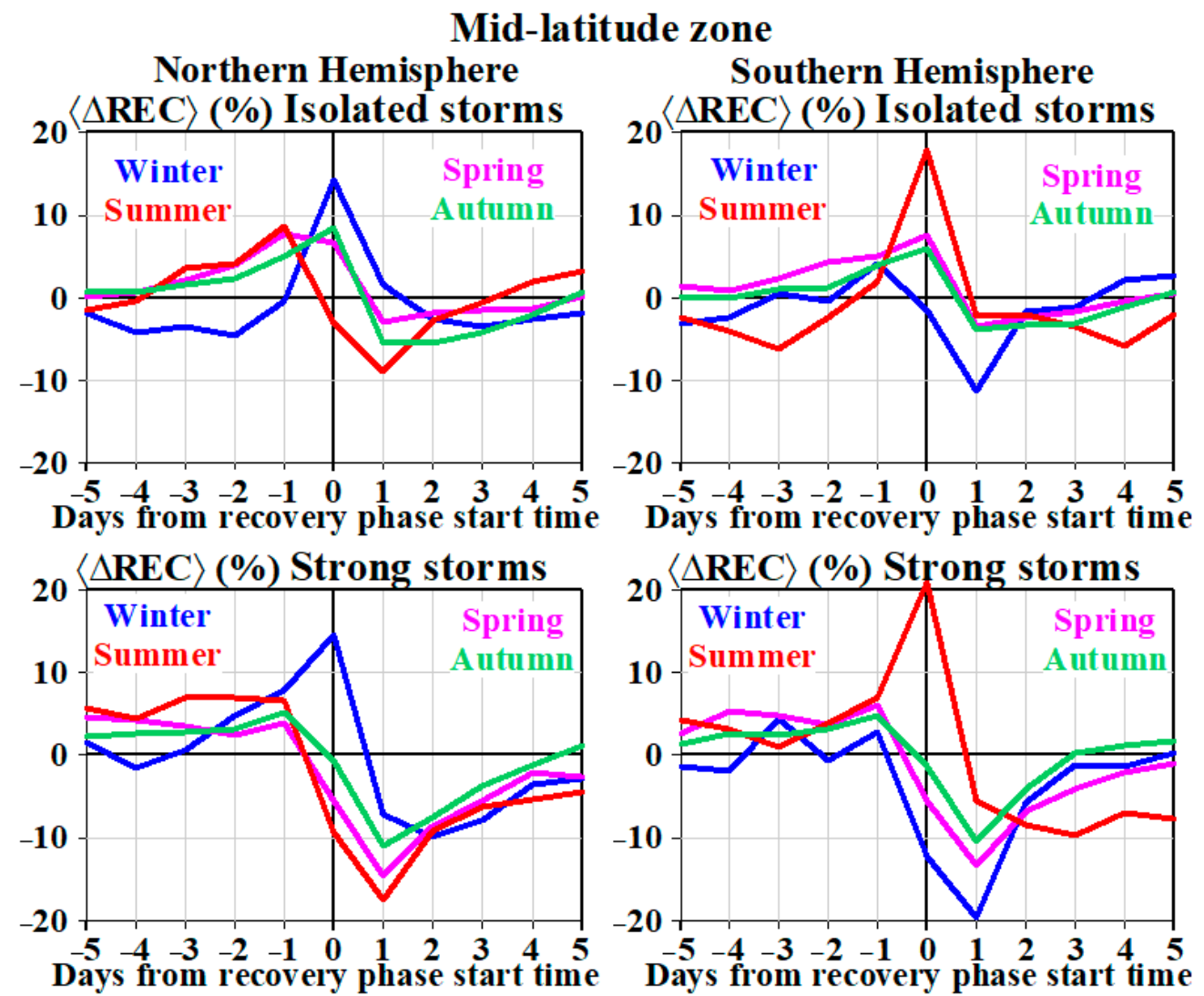

Figure 2. Average response in $\triangle R E C(\langle\triangle R E C)$ ) as function of day from beginning of geomagnetic storm recovery phase for midlatitude zones of Northern (left panel) and Southern (right panel) Hemispheres. Upper and lower panels show responses to isolated and strong storms, respectively. Blue, magenta, red, and green curves correspond to winter, spring, summer, and autumn, respectively.

Recovery phases of ionospheric storms consist in a monotonic decrease in the negative response from Day 1 to Day 5 for all seasons except for the local winter. For the local summer and equinoxes, the response on Day 5 can be weakly negative (under-recovery) or slightly positive (over-recovery or positive after-effects), which does not contradict the thermospheric storm concept. Unlike other seasons, in the case of the local winter, the negative response does not decrease during the recovery phase but increases compared to the response on Day 1. "Recovery scenarios" of the ionospheric responses for local winters do not repeat each other in different hemispheres. If in the Northern Hemisphere the behavior of the ionospheric response at least tends to the "expected recovery", then in the Southern Hemisphere the ionospheric response does not show any tendency to recovery. The reason for this strange behavior is currently unclear. 
At prestorm phases of isolated storms, we see a monotonic increase in ionospheric responses from Day -5 to Day -1 for all seasons except for the local winter (for the local winter, the increase begins on Day -3 or -2 ). In the prestorm phase of strong storms, we mainly see a certain positive background in ionospheric responses. This behavior is outside of the thermospheric storm concept. However, this effect is known as a prestorm enhancement. Detailed comparison with previous studies of prestorm enhancements is provided in Section 5.

Comparison of the $\langle\triangle R E C$ > behavior in the Northern and Southern Hemispheres shows both similarities and differences. A good qualitative agreement in the behavior of the Northern and Southern Hemisphere responses in terms of the local winter and summer is important, because this confirms the reliability of the performed statistical analysis. Thus, the close responses of the Northern and Southern Hemispheres demonstrate that the revealed behavior features (including prestorm and recovery phases) are the result of geomagnetic storms and not the effect of other processes. The main interhemispheric difference is that both the largest positive response and the largest negative response are stronger in the Southern Hemisphere compared to the Northern one. Possible reasons for this interhemispheric asymmetry are considered in Section 5.

\subsection{High-Latitude Zone}

Figure 3 shows $\langle\triangle R E C>$ as a function of day from the beginning of the geomagnetic storm recovery phase for the high-latitude zones of both hemispheres.

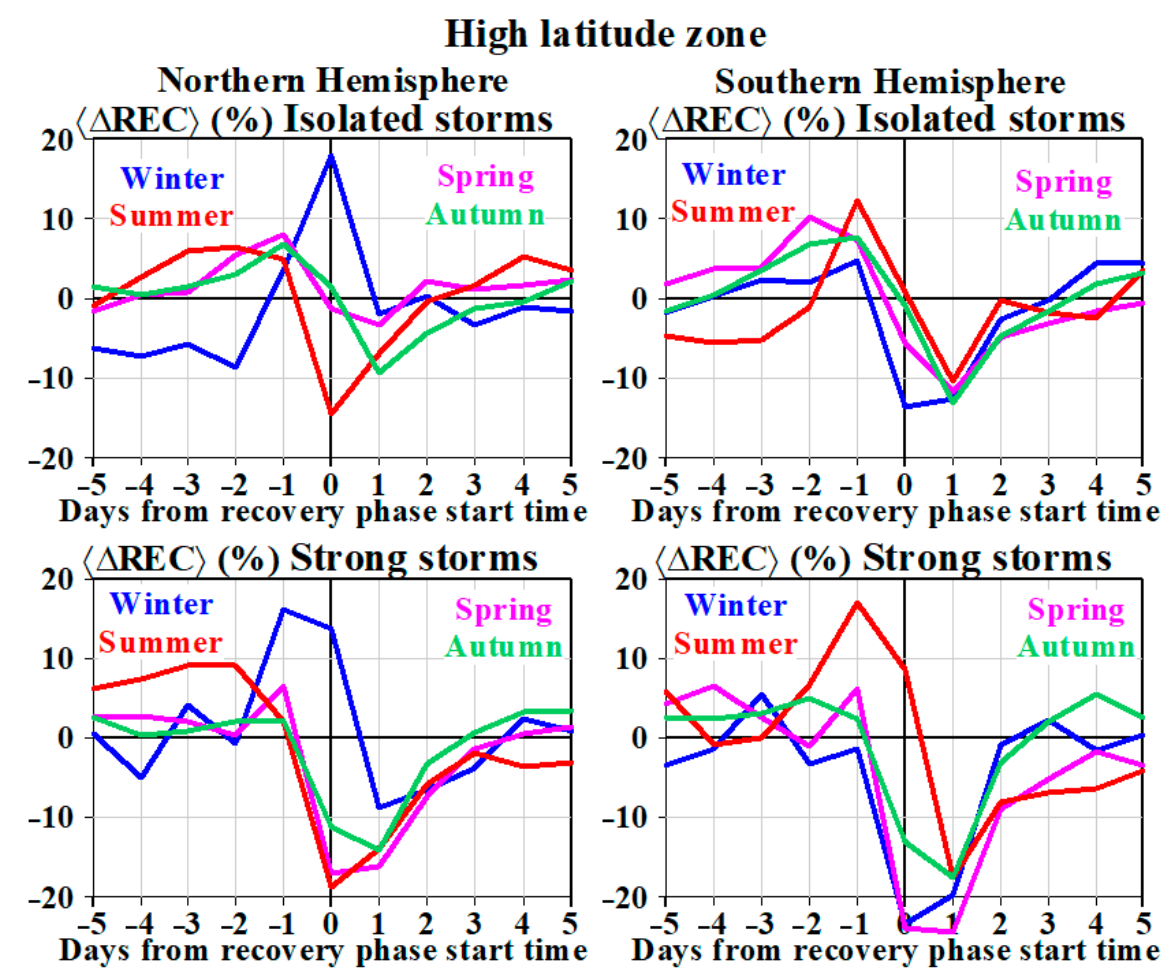

Figure 3. The same as Figure 2 but for high-latitude zones.

Let us consider the differences between ionospheric responses in high- and midlatitude zones. The largest negative response is mainly seen not on Day 1, but on Day 0, in contrast to the midlatitude zone. The largest negative response is mainly seen in the local summer as in the midlatitude zone. The formal exception is the case of strong storms in the Southern Hemisphere, when the largest response is seen on Day 1 in spring with a slight difference $(\sim 1 \%)$ from the local summer response on Day 0. The midlatitude seasonal dependence of the negative response (local winter-equinoxes-local summer) is well pronounced only for Day 0 of isolated storms in the Northern Hemisphere. In other 
cases, the responses at the equinoxes are close to the responses at solstices or even exceed the local summer negative responses. Comparison of the largest negative response amplitudes shows that the amplitudes are noticeably larger in the high-latitude zone on Day 0, while the amplitudes are close to each other in both zones on Day 1. In general, the mentioned differences follow from the thermospheric storm concept. If for the midlatitude zone the horizontal transfer of the disturbed composition is necessary for negative disturbances, then for the high-latitude zone there is no need for such a transfer. This explains the shift of the extreme negative response from Day 1 to Day 0 and the violation of the midlatitude seasonal dependence that is mainly determined by the efficiency of horizontal transfer.

In the high-latitude zone, the largest positive response is mainly seen not on Day 0 (as in the midlatitude zone), but on Day -1. An exception is the case of isolated storms in the Northern Hemisphere, when the largest response is seen on Day 0. As in the midlatitude zone, the largest positive response is always seen in the local winter. As for the general seasonal dependence of the positive response, for isolated storms it repeats the midlatitude trend (local winter-equinoxes-local summer), and for strong storms it has the form: local winter-other seasons. If the shift of the extreme negative response from Day 1 to Day 0 can be explained by the thermospheric storm concept, then the shift of the extreme positive response from Day 0 to Day -1 is less clear. The existence of the strong positive response at high latitudes (comparable to or even greater than the positive midlatitude response) is questionable in itself and will be discussed in detail in Section 4.

The recovery phase of the ionospheric storm in the high-latitude zone is generally close to that in the midlatitude zone but has two differences. The decrease in the negative response from Day 1 to Day 5 is not always strictly monotonic, which is most likely explained by the greater variability of the high-latitude ionosphere. The recovery phase in the local winter is not an exception from other seasons, possibly due to the large amount of molecular nitrogen in the high-latitude thermosphere, which stabilizes the recovery phase. The question is raised by the higher amplitudes of positive after-effects at high latitudes compared to those at midlatitudes. This result does not fit well with the concept of the thermospheric storm after-effects.

The prestorm phase in the high-latitude zone is generally close to that in the midlatitude zone but has two differences. For isolated storms, the largest positive response is seen not only on Day -1 (as in most cases) but also on Day -2 (summer in the Northern Hemisphere and spring in the Southern one), which actualizes the study of the prestorm phase. For strong storms, the positive background is less pronounced than in the midlatitude zone. The ionospheric response behavior in spring and autumn for strong storms in the Northern Hemisphere may be considered as a reference behavior in terms of the thermospheric storm concept.

The interhemispheric midlatitude asymmetry (the stronger both the positive and negative responses in the Southern Hemisphere compared to the Northern one) is not seen in the high-latitude zone. In the case of isolated storms, the opposite tendency is seen in the high-latitude region compared to midlatitudes. In the case of strong storms, the largest positive responses close to each other in both hemispheres and the largest negative response is formed in the Southern Hemisphere similarly to the midlatitude zone.

\subsection{Equatorial Zone}

Figure 4 shows the average response in $\triangle R E C(\measuredangle \triangle R E C)$ ) for the equatorial zone and the average value of $\Delta F 10.7(\langle\Delta F 10.7\rangle)$ as functions of day from the beginning of the geomagnetic storm recovery phase.

The ionospheric response in the equatorial zone differs significantly from the responses in highand midlatitudes. The amplitude of the response in the equatorial zone does not exceed $8 \%$, which is approximately 2.5 times less than the largest amplitudes of the responses in other zones. For isolated storms, the main effect in the equatorial zone consists of a positive response on Day 0 and a recovery phase of decreasing the positive response from Day 0 to Day 5. This behavior is expected in the thermospheric storm concept. The positive response is explained by the positive disturbance of the 
$n(\mathrm{O}) / n\left(\mathrm{~N}_{2}\right)$ ratio, which means that the atomic oxygen transfer dominates the molecular nitrogen transfer. The small amplitude of the response is explained by the largest distance from the heating zone and the lowest efficiency of the wind mechanism for the formation of positive disturbances compared with other latitudes. An unclear feature of the equatorial response to isolated storms is the spring behavior: the largest response on Day 0 ( $8 \%$ versus $5-6 \%$ in other seasons) and the most prolonged recovery phase with positive values on Day 5 . This issue is partially discussed in Section 4 by comparing autumn and spring storms. The prestorm phase of isolated storms in the equatorial zone is close to the prestorm phase in the midlatitude zone for the local winter. The negative background in the prestorm phase for the winter response and the negative autumn response at the recovery phase can be explained by the $\langle\Delta F 10.7>$ behavior (see upper right panel of Figure 4).

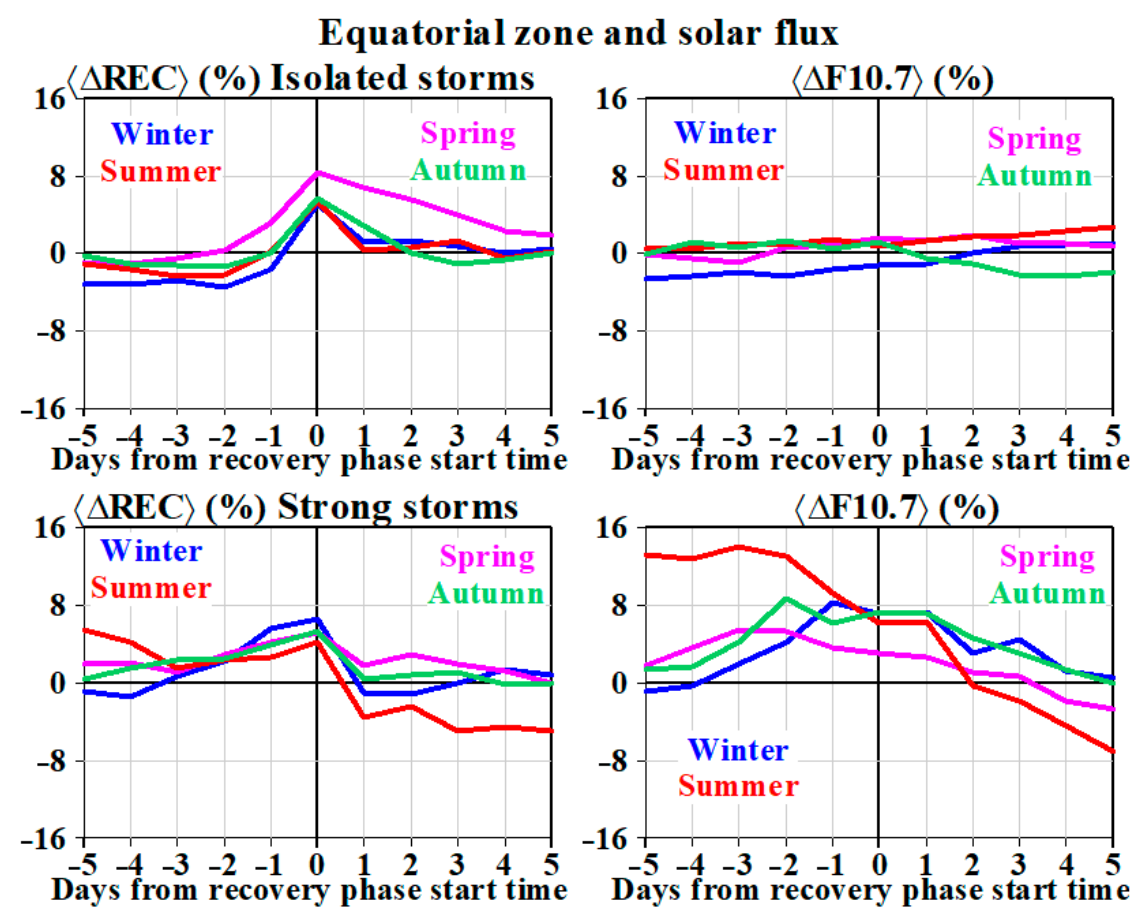

Figure 4. Average response in $\triangle R E C(\langle\triangle R E C\rangle)$ for equatorial zone (left panel) and average value of $\triangle F 10.7(<\triangle F 10.7\rangle$, right panel $)$ as functions of day from beginning of geomagnetic storm recovery. Upper and lower panels show $\langle\triangle R E C\rangle$ and $(<\triangle F 10.7>$ for isolated and strong storms, respectively. Blue, magenta, red, and green curves correspond to winter, spring, summer, and autumn, respectively.

For strong storms, as well as for isolated storms, the largest positive response is seen on Day 0 , excluding the summer prestorm phase, which will be explained below. Compared to isolated storms, the ionospheric response to strong storms on Day 1 becomes more negative (decrease in spring and autumn positive responses, and negative response in winter and summer). In accordance with the thermospheric storm concept, this effect is associated with the enrichment of the equatorial thermosphere with molecular nitrogen in the strong storm cases. For the strong storms, variations in the solar flux have a significant effect on the dynamics of the ionospheric response. The negative trend of summer response (Day -5 to Day 5) is most likely determined by the negative trend of $\langle\triangle F 10.7\rangle$ (see lower right panel of Figure 4). The prestorm phase of strong storms in the equatorial zone resembles the prestorm enhancement in the midlatitude zone for isolated storms; however, an increase in positive responses at the prestorm phase correlates with the $\langle\Delta F 10.7>$ behavior. Despite the lower $\langle\triangle F 10.7>$ values, the spring positive response dominates over responses in other seasons on Days 1-3, thus repeating the spring feature of isolated storms. 


\subsection{Signal-to-Noise Ratio}

In our statistical analysis, we calculated both the mean value of the $\triangle R E C(\langle\triangle R E C\rangle)$ and the standard deviation of $\triangle R E C(\sigma R E C)$. The average response $\langle\triangle R E C\rangle$ can be viewed as a signal, while the standard deviation $\sigma R E C$ can be viewed as noise characterizing the scatter of individual responses relative to the average value. Thus, the signal-to-noise ratio is defined as $\langle\triangle R E C>/ \sigma R E C$. Table 3 shows the cases of the highest signal-to-noise ratio for positive and negative responses in all latitudinal zones, both for isolated and strong storms (total 10 cases for each type of storm).

Table 3. Cases of highest signal-to-noise ratio for positive $(+)$ and negative (-) responses in all latitudinal zones both for isolated and strong storms.

\begin{tabular}{|c|c|c|c|c|c|}
\hline \multicolumn{6}{|c|}{ Isolated Storms } \\
\hline Latitude Zone & Day & Season & $\langle\Delta R E C\rangle$ & $\sigma R E C$ & $\langle\Delta R E C\rangle / \sigma R E C$ \\
\hline Equatorial $(+)$ & 0 & Spring & 8.3 & 9.1 & 0.9 \\
\hline Equatorial $(-)$ & -2 & Winter & -3.5 & 6 & -0.6 \\
\hline Northern Hemisphere midlatitude $(+)$ & 0 & Winter & 14.2 & 12.6 & 1.1 \\
\hline Northern Hemisphere midlatitude (-) & 1 & Summer & -8.9 & 11.2 & -0.8 \\
\hline Southern Hemisphere midlatitude $(+)$ & 0 & Summer & 17.7 & 12.6 & 1.4 \\
\hline Southern Hemisphere midlatitude (-) & 1 & Winter & -11.3 & 10.6 & -1.1 \\
\hline Northern Hemisphere high-latitude $(+)$ & 0 & Winter & 18 & 23.9 & 0.8 \\
\hline Northern Hemisphere high-latitude (-) & 0 & Summer & -14.4 & 9.2 & -1.6 \\
\hline Southern Hemisphere high-latitude $(+)$ & -1 & Summer & 12.4 & 19 & 0.6 \\
\hline Southern Hemisphere high-latitude (-) & 0 & Winter & -13.7 & 13 & -1.1 \\
\hline \multicolumn{6}{|c|}{ Strong Storms } \\
\hline Latitude Zone & Day & Season & $\langle\Delta R E C\rangle$ & $\sigma R E C$ & $\langle\Delta R E C\rangle / \sigma R E C$ \\
\hline Equatorial $(+)$ & 0 & Winter & 6.7 & 11.1 & 0.6 \\
\hline Equatorial $(-)$ & 3 & Summer & -5 & 7.8 & -0.6 \\
\hline Northern Hemisphere midlatitude $(+)$ & 0 & Winter & 14.6 & 13.3 & 1.1 \\
\hline Northern Hemisphere midlatitude (-) & 1 & Summer & -17.4 & 8.7 & -2.0 \\
\hline Southern Hemisphere midlatitude $(+)$ & 0 & Summer & 21 & 14 & 1.5 \\
\hline Southern Hemisphere midlatitude (-) & 1 & Winter & -19.6 & 11 & -1.8 \\
\hline Northern Hemisphere high-latitude (+) & -1 & Winter & 16.3 & 23.6 & 0.7 \\
\hline Northern Hemisphere high-latitude (-) & 0 & Summer & -18.7 & 9.8 & -1.9 \\
\hline Southern Hemisphere high-latitude $(+)$ & -1 & Summer & 17.1 & 21.1 & 0.8 \\
\hline Southern Hemisphere high-latitude (-) & 0 & Winter & -23.3 & 14 & -1.7 \\
\hline
\end{tabular}

In our previous statistical studies [6,7], when we used NmF2 and GEC as ionospheric characteristics, the signal-to-noise ratio was $\sim 1$ at best. Now, when we use $R E C$, the signal-to-noise ratio can reach $\sim 1.5$ for isolated storms and $\sim 2$ for strong storms. Increasing the signal-to-noise ratio is due to the following reasons. Compared to $N m F 2$, the use of $R E C$ reduces the scatter of individual responses relative to the average value. The midlatitude and high-latitude responses in $R E C$ have higher amplitudes compared to responses in GEC. The amplitudes of the responses in equatorial REC and GEC are close to each other. The interstorm pattern shows the higher signal-to-noise ratio for strong storms. As the storm intensifies, both $\langle\triangle R E C>$ and $\sigma R E C$ increase, but $<\triangle R E C>$ grows faster. Latitudinal pattern consists in the increase of both $\triangle \triangle R E C\rangle$ and $\sigma R E C$ with increasing latitude. As a result, the highest signal-to-noise ratio is achieved at midlatitudes. The lowest signal-to-noise ratios are seen in the following cases: (1) equatorial responses (both positive and negative) to strong storms; (2) equatorial negative response to isolated storms; and (3) high-latitude positive responses for both types of storms.

\section{Interpretation}

Here, using the described above statement of the problem and previously obtained model results (see Section 2.2), we analyzed the high- and low- latitude REC response to geomagnetic storms and 
interpreted the statistical analysis results. The model $R E C$ values for the high- and low-latitude zones were calculated in accordance with the scheme described in Section 2 for the observed REC values (see Section 2.1). We focused on the case studies of the moderate storm event on September 26, 2011 and the major event known as the 2015 St. Patrick's Day storm.

Analysis of the calculation results showed that the zonal and diurnal averaged storm-time disturbances of the zonal electric field do not exceed $0.15 \mathrm{mV} / \mathrm{m}$ (ExB drift velocity $\sim 4 \mathrm{~m} / \mathrm{s}$ ) at high latitudes and $0.004 \mathrm{mV} / \mathrm{m}(\mathrm{ExB}$ drift velocity $\sim 0.1 \mathrm{~m} / \mathrm{s})$ at low latitudes. The vertical plasma drift velocities at all latitudes do not exceed $0.1 \mathrm{~m} / \mathrm{s}$. Such velocities are much lower than the velocities of the vertical plasma transport due to the meridional thermospheric wind. This is the reason why we explain the REC effects on the basis of the thermospheric storm concept without considering the effects of electric fields.

Figure 5 demonstrates the storm-induced disturbances in thermospheric neutral temperature, neutral composition $\left(n(\mathrm{O})\right.$ and $\left.n\left(\mathrm{~N}_{2}\right)\right)$, thermospheric meridional wind, and daily-mean $R E C$ for the high and low latitudes on 17-22 March 2015.
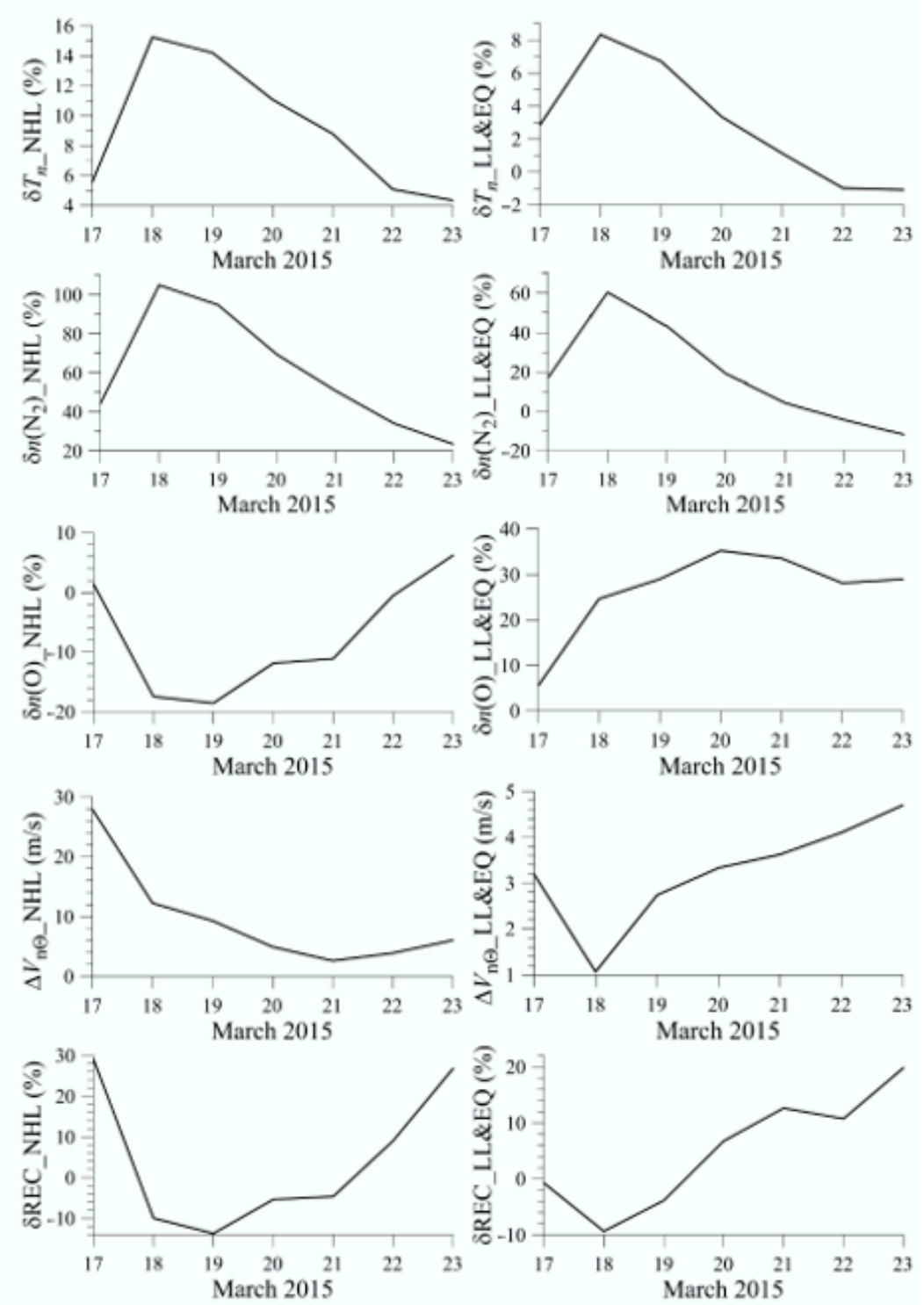

Figure 5. Simulated storm-induced disturbances in neutral temperature $\left(T_{n}\right)$, neutral composition $(n(\mathrm{O})$ and $n\left(\mathrm{~N}_{2}\right)$ ), meridional wind velocity $\left(\mathrm{V}_{n \Theta}\right)$, and $R E C$ (from top to bottom) for high (left panel) and low (right panel) latitudes on 17-22 March 2015. All characteristics are given for $250 \mathrm{~km}$. 
The thermospheric temperature disturbances at high and low latitudes show qualitatively identical behavior with the largest positive disturbances on $18 \mathrm{March}$. The largest temperature disturbances at high latitudes are two times greater than those at low latitudes. On 22-23 March, the temperature disturbances at low latitudes become negative. The same behavior is seen in the $n\left(\mathrm{~N}_{2}\right)$ disturbances, including the negative disturbances on 22-23 March. At high latitudes, the $n(\mathrm{O})$ disturbances are slightly positive on March 17, most negative on 19 March, and positive at the recovery phase on 22-23 March. At low latitudes, the $n(\mathrm{O})$ disturbances are totally positive with the largest amplitude on 20 March. At high latitudes, the equatorward meridional wind disturbances are the largest on 17 March. No significant wind disturbances were detected at low latitudes. The strong $(\sim 30 \%)$ positive disturbances in the high latitude REC on 17 March are caused by the additional equatorward meridional wind, while the positive disturbances on 22-23 March are due to the positive $n(\mathrm{O})$ disturbances. The negative REC disturbances on 18-21 March with the largest amplitude on 19 March are caused by the positive $n\left(\mathrm{~N}_{2}\right)$ disturbances and the negative $n(\mathrm{O})$ disturbances. Small negative disturbances in the low latitude REC on 17-19 March are attributed to the positive $n\left(\mathrm{~N}_{2}\right)$ disturbances competing with the positive $n(\mathrm{O})$ disturbances. The positive low latitude $R E C$ disturbances on 20-23 March are caused by the positive $n(\mathrm{O})$ disturbances.

Figure 6 shows the same characteristics as Figure 5 but for the moderate storm on 26-30 September 2011.
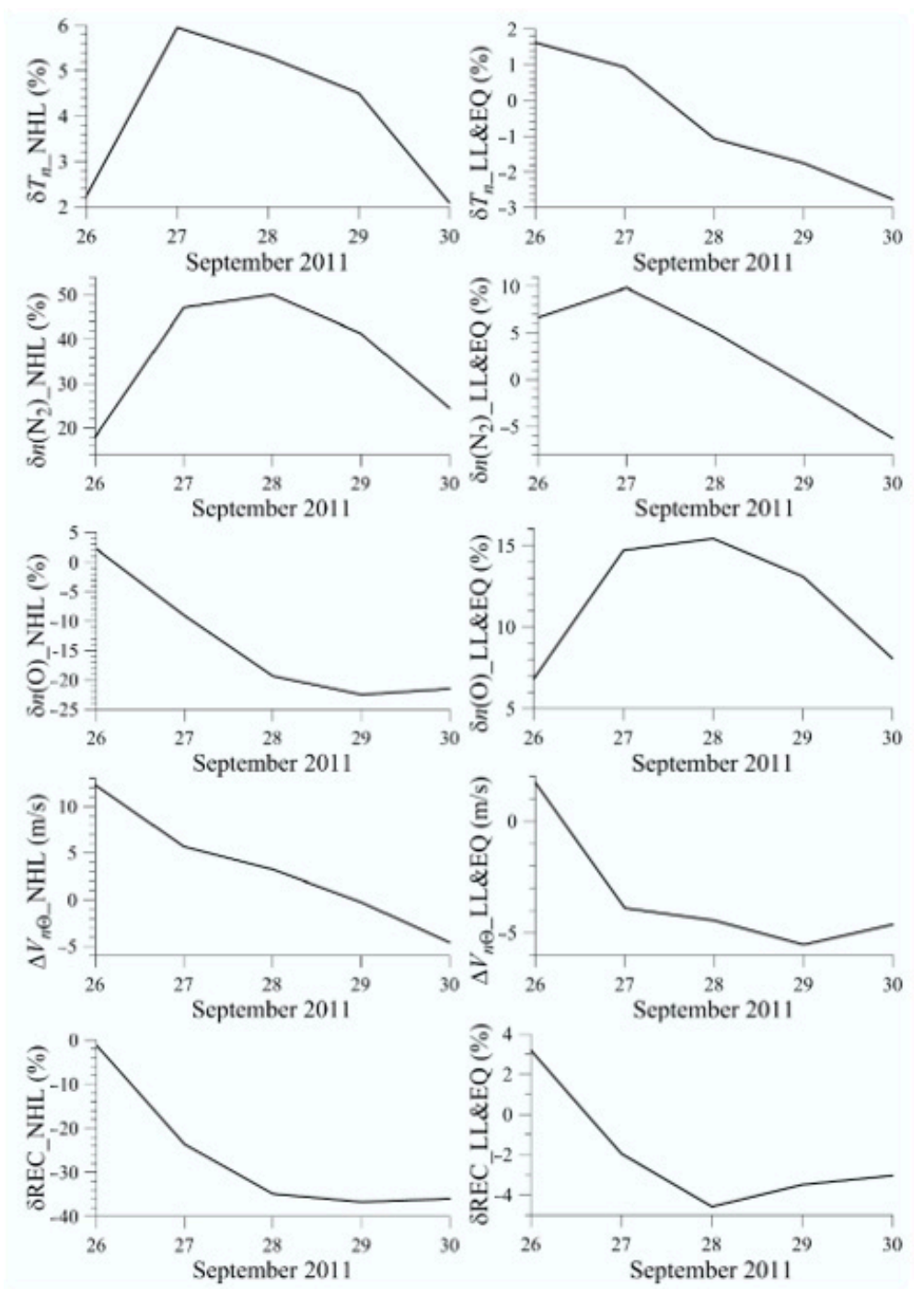

Figure 6. The same as Figure 5 but for but for moderate storm on 26-30 September 2011. 
The temperature and $n\left(\mathrm{~N}_{2}\right)$ disturbances for this storm are much weaker than those for the March one, which is apparently explained by the lower intensity of the September storm. If at the high latitudes the temperature and $n\left(\mathrm{~N}_{2}\right)$ disturbances exhibit a similar behavior, at low latitudes these behaviors are different. The temperature disturbance reaches only $2 \%$, which, however, leads to the increase in $n\left(\mathrm{~N}_{2}\right)$ by $10 \%$. At high latitudes, the $n(\mathrm{O})$ disturbances are totally negative in contrast to the March storm when there are positive $n(\mathrm{O})$ disturbances. At low latitudes, the positive $n(\mathrm{O})$ disturbances are much weaker compared to the March storm. The meridional wind disturbances during the September storm are insignificant. More negative $n(\mathrm{O})$ disturbances and weaker meridional wind disturbances during the September storm explain the more negative REC disturbances for the September storm compared to the March one.

The GSM TIP simulation allowed us to explain the following important points of the statistical analysis of $R E C$ response to geomagnetic storms for high and low latitudes. The significant positive high-latitude REC disturbance at the ionospheric storm main phase is explained by the strong positive disturbance of the equatorward meridional wind. The negative high-latitude $R E C$ disturbances at the ionospheric storm recovery phase are caused by negative $n(\mathrm{O})$ disturbances and $n\left(\mathrm{~N}_{2}\right)$ disturbances. The positive after-effects in the high-latitude $R E C$ are formed by the positive $n(\mathrm{O})$ disturbances. The most prolonged recovery phase of the equatorial $R E C$ response, revealed by the statistical analysis for spring storms, agrees with the difference between the low latitude responses to the spring and the autumn storm revealed by the GSM TIP simulation.

\section{Discussion}

The global coverage by the observational data and the performed simulation allowed us to make the detailed comparison of the obtained statistical results with the thermospheric storm concept $[1-4,6,12,13]$, implying that the main drivers of the ionospheric response are thermospheric composition and wind disturbances caused by heating in a high-latitude region.

In Section 4, we noted the insignificance of zonal mean and diurnal averaged values of the zonal electric field storm-time disturbance. This fact allows us to exclude the zonal electric field when we interpret the zonal mean and diurnal averaged REC responses at all latitudes. This can be explained by the fact that at different local times in different longitude sectors, both the additional storm-time eastward electric field and westward electric field arise during storm time, which, under zonal and diurnal averaging, leads to disturbances close to zero. We consider REC responses in large latitudinal zones that include various large-scale latitudinal features. Thus, the high-latitude zone includes both the main ionospheric trough and the tongue of ionization, while the equatorial zone includes both the equatorial trough and the EIA crests. All of these features are enhanced during storm time due to increased electric fields $[18,56,57]$. The electron density increases in the tongue of ionization and EIA crests regions accompanied by the electron density decrease in the main ionospheric trough and equatorial trough. That also decreases the significance of the electric fields effects to interpret the zonal mean and diurnal averaged ionospheric responses to geomagnetic storms. An argument supports the small influence of the storm-time zonal electric field on the zonal mean and diurnal averaged REC effects is that the amplitude of the response in the equatorial zone approximately 2.5 times less than the largest response amplitudes in other zones. We explain small amplitude of the response by the largest distance from the heating zone and the lowest efficiency of the wind mechanism for the formation of positive disturbances compared to the other latitudes. It is important to emphasize that the electric field is insignificant only for the zonal and diurnal averaged REC disturbances. Without averaging, the electric field effects on the electron density can be comparable and sometimes exceed the effects of storm-time thermospheric wind and neutral composition.

The seasonal pattern of the signal-to-noise ratio $\langle\triangle R E C \gg / \sigma R E C$ is that the negative local summer responses are more deterministic than the positive local winter responses. Apparently, this is due to more stable disturbances of molecular nitrogen as compared with disturbances of atomic oxygen and neutral wind. For the midlatitude zones of both hemispheres, the ionospheric response at the main 
phase of the ionospheric storm agrees with the thermospheric storm concept including the seasonal dependence of the ionospheric responses. The obtained seasonal dependence is entirely consistent with the statistical studies [58-60]. The midlatitude ionospheric responses at the recovery phase do not contradict the thermospheric storm concept for the local summer and equinoxes. However, the largest positive after-effects in midlatitude REC in the local summer are inconsistent with the findings of the statistical study [6], where the spring was identified as the most favorable season for positive after-storm effects in NmF2 over Kaliningrad and Irkutsk. For the local winter, we cannot explain the increase in the negative response during the recovery phase through the thermospheric storm concept, and the reason for such an unexpected dynamic is unclear currently. Below we discuss the prestorm enhancement and the interhemispheric asymmetry (larger amplitudes of ionospheric responses in the Southern Hemisphere in comparison to the Northern one). Both disagrees the thermospheric storm concept.

For the high-latitude zones of both hemispheres, the ionospheric response at the main phase of the ionospheric storm agrees with the thermospheric storm concept. The difference between the high- and midlatitude seasonal behaviors of the ionospheric response also may be explained by this concept (for the midlatitude zone the horizontal transfer of the disturbed composition is necessary for negative disturbances, while for the high-latitude zone there is no need for such a transfer). The high-latitude ionospheric responses at the recovery phase do not contradict the thermospheric storm concept. The GSM TIP simulation showed that the existence of the strong positive response at high latitudes (comparable to or even greater than the positive midlatitude response) may be explained by the strong impact of the neutral wind at the main phase of the geomagnetic storm. A positive response one day before the beginning of the recovery phase (Day -1) may be associated with storms that have the recovery phase on Day 0, while the main phase of the storm occurs on the previous day $($ Day -1$)$. In such situations, the positive response is the net effect of the storm main phase. At present, this explanation is a version requiring verification based on numerical modeling and statistical analysis. The prestorm enhancement in the high-latitude zone is generally close to that in the midlatitude zone.

For the equatorial zone, the ionospheric response as a whole fits into the thermospheric storm concept considering the solar flux influence. An unclear feature of the equatorial zone is the spring response with the largest amplitude and most prolonged recovery phase compared to other seasons. The GSM TIP simulation revealed this feature in the difference between the equatorial responses to the spring and the autumn storm. However, this is a feature of only two storms, and the explanation of the general effect is the subject of further research.

The interhemispheric asymmetry of ionospheric responses to geomagnetic storms is not a phenomenon revealed for the first time. The statistical study [60] found significant differences between the two hemispheres: the storm induced changes in TEC at $35^{\circ} \mathrm{S}$ were more positive (or less negative) than those at $35^{\circ} \mathrm{N}$. In our study, the ionospheric responses in the Southern Hemisphere are more positive in the local winter (as well as in the study [60]) but more negative in the local summer (in contrast to the study [60]). Most likely, the reason for the differences is related to the different choice of season lengths and the different set of observational data. In the study [60], the winter is the October-March period and the summer is the April-September period, while in our study, the winter and summer are $~ 91$-day intervals centered around the winter and summer solstices. The study [60] uses the TEC data from several stations, while our study uses the TEC data averaged over the latitude zones. It is interesting that the finding of the study [60], that "increased mixing of the atmosphere, during disturbed conditions, tends to reduce the normal difference in composition between the two hemispheres", is valid for our statistical pattern. For the local winter, the background electron density in the Southern Hemisphere is lower than in the Northern one; and vice versa for the local summer, the background electron density in the Southern Hemisphere is higher than in the Northern one [61]. Thus, the ionospheric responses in the Southern Hemisphere are more positive in the local winter and more negative in the local summer, reducing the background difference between the hemispheres. 
The study [62] analyzed the hemispheric asymmetry in the thermospheric density response to geomagnetic storms. They found that the maximum density enhancement averaged across the dayside southern polar region was about 1.52 times of that in the northern polar region for the 03-07 April 2004 geomagnetic storm. This result indicated that the Southern Hemisphere suffers more from strong driving conditions. However, analysis of other storms led to the conclusion that the hemispheres reacted about the same in all seasons except vernal equinox. It was suggested that during summer and winter competing effects cancel each other. The latter does not agree with our statistical pattern, where the interhemispheric asymmetry (stronger response to magnetic storm in the Southern Hemisphere) manifests itself precisely at solstices. The reason for the disagreement probably is due to the difference between the electron density and thermospheric density responses caused by the strong influence of the neutral wind on the electron density. An additional reason may be the lack of the division into different types of storms in [62]. Despite seasonal differences, there is a general pattern of the interhemispheric asymmetry in the electron density and thermospheric density responses: the Southern Hemisphere is more sensitive to geomagnetic storms than the Northern one.

Prestorm enhancement is an increase in electron density (manifested as an increase in critical frequency foF 2 or NmF2 or TEC) during the period preceding the geomagnetic storm onset. The detailed analysis of research on the prestorm enhancement can be found in the review [5]. According to this review, the problem of the physical mechanisms of the prestorm effect is absolutely obscure. The study [63] concluded that the dominant mechanism of the prestorm enhancement remains to be uncovered, but potential mechanisms such as (1) solar flares, (2) soft particle precipitation in dayside cusp, (3) magnetospheric electric field penetration, (4) auroral region activity expressed via the $A E$ index, and (5) Mikhailov's quiet-time F2-layer disturbances [64] can be ruled out. However, Mikhailov and Perrone [65] argue that in all the cases considered, there were the following mechanisms of NmF2 enhancement: either moderate auroral activity (the excluded case 4 in [63]) or some previous days presenting the class of positive Q-disturbance events (the excluded case 5 in [63]). An important finding from study [63] is that the increase in NmF2 is not accompanied by an increase in peak height $h m F 2$, which excludes a wind induced enhancement of $N m F 2$. Liu et al. [66] suggested that vertical plasma drift or zonal electric drift could be a possible cause of the low-latitude prestorm enhancement. The increase in the vertical plasma drift or zonal electric field could be associated with either an aftermath of a previous geomagnetic activity or directly mapping to the equatorial ionosphere from the solar wind electric fields, effects of planetary atmospheric waves, and so on.

The performed statistical analysis made the following contribution to the study of the prestorm enhancement problem. For isolated storms, the prestorm enhancement manifests itself as a monotonic increase in the averaged $\triangle R E C$ within five days preceding the geomagnetic storm onset. Such a behavior agrees with the interpretation of prestorm enhancement as long-term positive Q-disturbances in the form of a succession of days with similar NmF2 diurnal variations, which can be cut off by a magnetic storm [64]. The prestorm enhancement in $\triangle R E C$ is the largest in summer and spring for the Northern Hemisphere and in spring for the Southern Hemisphere. Such seasonal tendency partly agrees with higher occurrence of $N m F 2$ prestorm enhancements in the summer [63]. For strong storms, the prestorm enhancement manifests itself as a positive background in the averaged $\triangle R E C$. The difference from the case of isolated storms may be associated with the superposition of effects from other storms (strong storms are mainly nonisolated) or with different mechanisms of prestorm enhancements for strong and isolated storms.

\section{Conclusions}

We obtained a statistical pattern of the response in regional electron content to geomagnetic storms on a global scale, which allowed us to interpret the results with using the upper atmosphere model, to make the detailed comparison with the thermospheric storm concept, and to compare the obtained pattern with previous statistical studies. 
Most of the statistical pattern agrees with the thermospheric storm concept and the previous statistical studies. These are ionospheric responses at ionospheric storm main phases including their seasonal dependences for the high- and midlatitudes and some features of ionospheric responses at recovery phases.

Based on model results we obtained that the contribution of electric fields to the interpretation of the zonal and diurnal averaged storm-time REC disturbances at all latitudes is insignificant. The existence of the strong positive response at high latitudes (comparable to or even greater than the positive midlatitude response) may be explained by the strong impact of the neutral wind at the main phase of the geomagnetic storm. The positive after-storm effects at different latitudes are caused by the positive $n(\mathrm{O})$ disturbances.

Some of the statistical patterns are inconsistent with the thermospheric storm concept and contradict the previous statistical studies. There are negative midlatitude ionospheric responses at recovery phases in the local winter, the domination of the spring response in the equatorial zone, seasonal features of the positive after-effects, the interhemispheric asymmetry of ionospheric responses, and the prestorm enhancement.

The contribution of the performed statistical analysis to the studies of the interhemispheric asymmetry and the prestorm enhancement is as follows. According to the obtained statistical pattern, the interhemispheric asymmetry is that both the largest positive response in the local winter and the largest negative response in the local summer are stronger in the Southern Hemisphere compared to the Northern one. Such finding differs from the previous studies. According to the obtained statistical pattern, the prestorm enhancement before isolated storms is a five-day monotonic increase in the positive disturbance of the regional electron content. This formulation of the prestorm enhancement has not been previously proposed.

An important finding of this study is that the close midlatitude ionospheric responses of the Northern and Southern Hemispheres demonstrate that the revealed behavior features (including prestorm and recovery phases) are the result of geomagnetic storms and not the effect of other processes.

The use of regional electron content as the ionospheric characteristic allowed us to reduce the scatter of individual responses relative to the average value compared to using peak electron density and global electron content as ionospheric characteristics.

Author Contributions: Conceptualization, K.G.R., M.V.K., Y.V.Y., and V.V.K.; methodology, K.G.R., Y.V.Y., and A.M.V.; software, K.G.R., M.V.K., Y.V.Y., V.V.K., and A.M.V.; validation, K.G.R., M.V.K., and Y.V.Y.; formal analysis, K.G.R., M.V.K., Y.V.Y., and V.V.K.; investigation, K.G.R., M.V.K., Y.V.Y., and V.V.K.; data curation, Y.V.Y. and A.M.V.; writing — original draft preparation, K.G.R., M.V.K., Y.V.Y., and V.V.K.; writing—review and editing, K.G.R., M.V.K., Y.V.Y., and V.V.K.; visualization, K.G.R. and M.V.K.; supervision, K.G.R.; project administration, K.G.R.; funding acquisition, K.G.R., M.V.K., Y.V.Y., V.V.K., and A.M.V. All authors have read and agreed to the published version of the manuscript.

Funding: The reported study was funded by RFBR, project number 18-05-00594; and partly by The Ministry of Science and Higher Education of the Russian Federation (Basic Research program II.12).

Acknowledgments: The authors are grateful to the CODE laboratory for the global ionospheric maps available at $\mathrm{ftp} / / / \mathrm{ftp}$.unibe.ch/aiub/CODE/, as well as to the NASA's Space Physics Data Facility (SPDF) for geomagnetic and solar indices data available at http://omniweb.gsfc.nasa.gov/form/dx1.html. The initial series of regional electron content were obtained using the SIMuRG system (https://simurg.iszf.irk.ru/).

Conflicts of Interest: The authors declare no conflict of interest.

\section{References}

1. Buonsanto, M.J. Ionospheric Storms: A Review. Space Sci. Rev. 1999, 88, 563-601. [CrossRef]

2. Mendillo, M. Storms in the ionosphere: Patterns and processes for total electron content. Rev. Geophys. 2006, 44, RG4001. [CrossRef]

3. Mikhailov, A.V. Ionospheric F2-Layer Storms. Fisica de la Tierra 2000, 12, 223-262. 
4. Prölss, G.W. Ionospheric storms at mid-latitudes: A short review. In Midlatitude Ionospheric Dynamics and Disturbances, 1st ed.; Kintner, P.M., Jr., Coster, A.J., Fuller-Rowell, T., Mannucci, A.J., Mendillo, M., Heelis, R., Eds.; American Geophys. Union: Washington, DC, USA, 2008; Volume 181, pp. 9-24.

5. Danilov, A.D.; Konstantinova, A.V. Ionospheric precursors of geomagnetic storms. 1. A review of the problem. Geomagn. Aeron. 2019, 59, 554-566. [CrossRef]

6. Ratovsky, K.G.; Klimenko, M.V.; Klimenko, V.V.; Chirik, N.V.; Korenkova, N.A.; Kotova, D.S. After-effects of geomagnetic storms: Statistical analysis and theoretical explanation. Solar Terrestrial Phys. 2018, 4, $26-32$. [CrossRef]

7. Ratovsky, K.G.; Klimenko, M.V.; Yasyukevich, Y.V.; Klimenko, V.V. Statistical analysis of ionospheric global electron content response to geomagnetic storms. In Proceedings of the 2019 Russian Open Conference on Radio Wave Propagation (RWP), Kazan, Russia, 1-6 July 2019; pp. 183-186. [CrossRef]

8. Afraimovich, E.L.; Astafyeva, E.I.; Zhivetiev, I.V.; Oinats, A.V.; Yasyukevich, Y.V. Global electron content during solar cycle 23. Geomagn. Aeron. 2008, 48, 187-200. [CrossRef]

9. Liu, L.; Wan, W.; Ning, B.; Zhang, M.-L. Climatology of the mean total electron content derived from GPS global ionospheric maps. J. Geophys. Res. Space Phys. 2009, 114, A06308. [CrossRef]

10. Liu, J.; Hernández-Pajares, M.; Liang, X.; An, J.; Wang, Z.; Chen, R.; Sun, W.; Hyyppä, J. Temporal and spatial variations of global ionospheric total electron content under various solar conditions. J. Geod. 2017, 91, 485-502. [CrossRef]

11. Nava, B.; Rodríguez-Zuluaga, J.; Alazo-Cuartas, K.; Kashcheyev, A.; Migoya-Orué, Y.; Radicella, S.M.; Amory-Mazaudier, C.; Fleury, R. Middle- and low-latitude ionosphere response to 2015St. Patrick's Day geomagnetic storm. J. Geophys. Res. Space Phys. 2016, 121, 3421-3438. [CrossRef]

12. Mayr, H.G.; Harris, I.; Spencer, N.W. Some properties of upper atmosphere dynamics. Rev. Geophys. 1978, 16, 539-565. [CrossRef]

13. Field, P.R.; Rishbeth, H. The response of the ionospheric F2-layer to geomagnetic activity: An analysis of worldwide data. J. Atmos. Solar Terr. Phys. 1997, 59, 163-180. [CrossRef]

14. Burns, A.G.; Killeen, T.L.; Deng, W.; Carignan, G.R.; Roble, R.G. Geomagnetic storm effects in the low- and middle-latitude upper thermosphere. J. Geophys. Res. Space Phys. 1995, 100, 14673-14691. [CrossRef]

15. Cai, X.; Burns, A.G.; Wang, W.; Qian, L.; Solomon, S.C.; Eastes, R.W.; Pedatella, N.; Daniell, R.E.; McClintock, W.E. The two-dimensional evolution of thermospheric $\Sigma \mathrm{O} / \mathrm{N} 2$ response to weak geomagnetic activity during solar-minimum observed by GOLD. Geophys. Res. Lett. 2020, 47, e2020GL088838. [CrossRef]

16. Lin, C.H.; Richmond, A.D.; Heelis, R.A.; Bailey, G.J.; Lu, G.; Liu, J.Y.; Yeh, H.C.; Su, S.-Y. Theoretical study of the low- and midlatitude ionospheric electron density enhancement during the October 2003 superstorm: Relative importance of the neutral wind and the electric field. J. Geophys. Res. Space Phys. 2005, 110, A12312. [CrossRef]

17. Lei, J.; Wang, W.; Burns, A.G.; Solomon, S.C.; Richmond, A.D.; Wiltberger, M.; Goncharenko, L.P.; Coster, A.; Reinisch, B.W. Observations and simulations of the ionospheric and thermospheric response to the December 2006 geomagnetic storm: Initial phase. J. Geophys. Res. Space Phys. 2008, 113, A01314. [CrossRef]

18. Balan, N.; Shiokawa, K.; Otsuka, Y.; Watanabe, S.; Bailey, G.J. Super plasma fountain and equatorial ionization anomaly during penetration electric field. J. Geophys. Res. Space Phys. 2009, 114, A03310. [CrossRef]

19. Balan, N.; Shiokawa, K.; Otsuka, Y.; Kikuchi, T.; Lekshmi, D.V.; Kawamura, S.; Yamamoto, M.; Bailey, G.J. A physical mechanism of positive ionospheric storms at low latitudes and midlatitudes. J. Geophys. Res. Space Phys. 2010, 115, A02304. [CrossRef]

20. Klimenko, M.V.; Klimenko, V.V.; Despirak, I.V.; Zakharenkova, I.E.; Kozelov, B.V.; Cherniakov, S.M.; Andreeva, E.S.; Tereshchenko, E.D.; Vesnin, A.M.; Korenkova, N.A.; et al. Disturbances of the thermosphere-ionosphere-plasmasphere system and auroral electrojet at $30^{\circ} \mathrm{E}$ longitude during the St. Patrick's Day geomagnetic storm on 17-23 March 2015. J. Atmos. Solar Terr. Phys. 2018, 180, 78-92. [CrossRef]

21. Klimenko, M.V.; Zakharenkova, I.E.; Klimenko, V.V.; Lukianova, R.Y.; Cherniak, I.V. Simulation and observations of the polar tongue of ionization at different heights during the 2015 St. Patrick's Day storm. Space Weather 2019, 17, 1073-1089. [CrossRef]

22. Rishbeth, H.; Garriott, O.K. Introduction to Ionospheric Physics; International Geophysics Series 14; Academic Press: New York, NY, USA; London, UK, 1969. 
23. Mannucci, A.J.; Tsurutani, B.T.; Iijima, B.A.; Komjathy, A.; Saito, A.; Gonzalez, W.D.; Guarnieri, F.L.; Kozyra, J.U.; Skoug, R. Dayside global ionospheric response to the major interplanetary events of October 29-30, 2003 "Halloween Storms". Geophys. Res. Lett. 2005, 32, L12S02. [CrossRef]

24. Heelis, R.A.; Sojka, J.J.; David, M.; Schunk, R.W. Stormtime density enhancements in the middle latitude dayside ionosphere. J. Geophys. Res. Space Phys. 2009, 114, A03315. [CrossRef]

25. Ratovsky, K.G.; Klimenko, M.V.; Vasilyev, R.V.; Klimenko, V.V.; Podlesnyi, A.V. Vertical plasma transport in the ionosphere over Irkutsk during St. Patrick's Day geomagnetic storm: Observations and modeling. Adv. Space Res. 2020. [CrossRef]

26. Rishbeth, H.; Heelis, R.A.; Makela, J.J.; Basu, S. Storming the Bastille: The effect of electric fields on the ionospheric F-layer. Ann. Geophys. 2010, 28, 977-981. [CrossRef]

27. Heelis, R.A.; Makela, J.J.; Basu, S. Reply to Tsurutani et al.'s comment on "Storming the Bastille: The effect of electric fields on the ionospheric F-layer" by Rishbeth et al. (2010). Ann. Geophys. 2013, 31, 151-152. [CrossRef]

28. Tsurutani, B.T.; Mannuccci, A.J.; Verkhoglyadova, O.P.; Lakhina, G.S. Comment on “Storming the Bastille: The effect of electric fields on the ionospheric F-layer" by Rishbeth et al. (2010). Ann. Geophys. 2013, 31, 145-150. [CrossRef]

29. Dmitriev, A.V.; Suvorova, A.V.; Klimenko, M.V.; Klimenko, V.V.; Ratovsky, K.G.; Rakhmatulin, R.A.; Parkhomov, V.A. Predictable and unpredictable ionospheric disturbances during St. Patrick's Day magnetic storms of 2013 and 2015 and on 8-9 March 2008. J. Geophys. Res. Space Phys. 2017, 122, 2398-2423. [CrossRef]

30. Förster, M.; Namgaladze, A.A.; Yurik, R.Y. Thermospheric composition changes deduced from geomagnetic storm modeling. Geophys. Res. Lett. 1999, 26, 2625-2628. [CrossRef]

31. Mayr, H.G.; Hedin, A.E. Significance of large scale circulation in magnetic storm characteristics with application to AE-C neutral composition data. J. Geophys. Res. Space Phys. 1977, 82, 1227-1234. [CrossRef]

32. Fuller-Rowell, T.J.; Codrescu, M.V.; Moffett, R.J.; Quegan, S. Response of the thermosphere and ionosphere to geomagnetic storms. J. Geophys Res. Space Phys. 1994, 99, 3893-3914. [CrossRef]

33. Burns, A.G.; Killeen, T.L.; Roble, R.G. A theoretical study of thermospheric composition perturbations during an impulsive geomagnetic storm. J. Geophys. Res. Space Phys. 1991, 96, 14153-14167. [CrossRef]

34. Balan, N.; Alleyne, H.; Otsuka, Y.; Lekshmi, D.V.; Fejer, B.G.; McCrea, I. Relative effects of electric field and neutral wind on positive ionospheric storms. Earth Planets Space 2009, 61, 439-445. [CrossRef]

35. Crowley, G.; Hackert, C.L.; Meier, R.R.; Strickland, D.J.; Paxton, L.J.; Pi, X.; Mannucci, A.; Christensen, A.B.; Morriston, D.; Bust, G.S.; et al. Global thermosphere-ionosphere response to onset of 20 November 2003 storm. J. Geophys. Res. Space Phys. 2006, 111, A10S18. [CrossRef]

36. Romanova, E.B.; Tashchilin, A.V.; Zherebtsov, G.A.; Pirog, O.M.; Polekh, N.M.; Smirnov, V.F.; Stepanov, A.E.; Jiankui, S.S.; Xiao, W. Modeling of the seasonal effects of geomagnetic storms in the eastern Asian ionosphere. Int. J. Geomagn. Aeron. 2006, 6, GI3004. [CrossRef]

37. Klimenko, M.V.; Klimenko, V.V.; Bessarab, F.S.; Zakharenkova, I.E.; Kotova, D.S.; Nosikov, I.A.; Ratovsky, K.G.; Stepanov, A.E.; Vorobjev, V.G.; Yagodkina, O.I. Influence of geomagnetic storms of September 26-30, 2011, on the ionosphere and HF radiowave propagation. I. Ionospheric effects. Geomagn. Aeron. 2015, 55, 744-762. [CrossRef]

38. Klimenko, M.V.; Klimenko, V.V.; Zakharenkova, I.E.; Ratovsky, K.G.; Korenkova, N.A.; Yasyukevich, Y.V.; Mylnikova, A.A.; Cherniak, I.V. Similarity and differences in morphology and mechanisms of the foF2 and TEC disturbances during the geomagnetic storms on 26-30 September 2011. Ann. Geophys. 2017, 35, 923-938. [CrossRef]

39. Fuller-Rowell, T.J.; Codrescu, M.V.; Rishbeth, H.; Moffett, R.J.; Quegan, S. On the seasonal response of the thermosphere and ionosphere to geomagnetic storms. J. Geophys. Res. Space Phys. 1996, 101, 2343-2353. [CrossRef]

40. Hernández-Pajares, M.; Juan, J.M.; Sanz, J.; Orus, R.; Garcia-Rigo, A.; Feltens, J.; Komjathy, A.; Schaer, S.C.; Krankowski, A. The IGS VTEC maps: A reliable source of ionospheric information since 1998. J Geod. 2009, 83, 263-275. [CrossRef]

41. Schaer, S.; Beutler, G.; Rothacher, M. Mapping and predicting the ionosphere. In Proceedings of the IGS AC Workshop, Darmstadt, Germany, 9-11 February 1998; pp. 307-320. 
42. Jee, G.; Lee, H.-B.; Kim, Y.H.; Chung, J.-K.; Cho, J. Assessment of GPS global ionosphere maps (GIM) by comparison between CODE GIM and TOPEX/Jason TEC data: Ionospheric perspective. J. Geophys. Res. Space Phys. 2010, 115, A10319. [CrossRef]

43. Roma-Dollase, D.; Hernández-Pajares, M.; Krankowski, A.; Kotulak, K.; Ghoddousi-Fard, R.; Yuan, Y.; Li, Z.; Zhang, H.; Shi, C.; Wang, C.; et al. Consistency of seven different GNSS global ionospheric mapping techniques during one solar cycle. J. Geod. 2018, 92, 691-706. [CrossRef]

44. Shepherd, S.G. Altitude-adjusted corrected geomagnetic coordinates: Definition and functional approximations. J. Geophys. Res. Space Phys. 2014, 119, 7501-7521. [CrossRef]

45. Astafyeva, E.I.; Afraimovich, E.L.; Oinats, A.V.; Yasukevich, Y.V.; Zhivetiev, I.V. Dynamics of global electron content in 1998-2005 derived from global GPS data and IRI modeling. Adv. Space Res. 2008, 42, 763-769. [CrossRef]

46. Gonzalez, W.D.; Joselyn, J.A.; Kamide, Y.; Kroehl, H.W.; Rostoker, G.; Tsurutani, B.T.; Vasyliunas, V.M. What is a Geomagnetic Storm? J. Geophys. Res. Space Phys. 1994, 99, 5771-5792. [CrossRef]

47. Cander, L.R.; Mihajlovic, S.J. Forecasting ionospheric structure during the great geomagnetic storms. J. Geophys. Res. Space Phys. 1998, 103, 391-398. [CrossRef]

48. Namgaladze, A.A.; Korenkov, Y.N.; Klimenko, V.V.; Karpov, I.V.; Bessarab, F.S.; Surotkin, V.A.; Glushchenko, T.A.; Naumova, N.M. Global model of the thermosphere-ionosphere-protonosphere system. Pure Appl. Geophys. 1988, 127, 219-254. [CrossRef]

49. Korenkov, Y.N.; Klimenko, V.V.; Förster, M.; Bessarab, F.S.; Surotkin, V.A. Calculated and observed ionospheric parameters for Magion-2 passage above EISCAT on July 31, 1990. J. Geophys. Res. Space Phys. 1998, 103, 14697-14710. [CrossRef]

50. Klimenko, M.V.; Klimenko, V.V.; Bryukhanov, V.V. Numerical modeling of the equatorial electrojet UT-variation on the basis of the model GSM TIP. Adv. Radio Sci. 2007, 5, 385-392. [CrossRef]

51. Klimenko, M.V.; Klimenko, V.V.; Ratovsky, K.G.; Goncharenko, L.P.; Sahai, Y.; Fagundes, P.R.; de Jesus, R.; de Abreu, A.J.; Vesnin, A.M. Numerical modeling of ionospheric effects in the middle- and low-latitude F region during geomagnetic storm sequence of 9-14 September 2005. Radio Sci. 2011, 46, RS0D03. [CrossRef]

52. Feshchenko, E.Y.; Maltsev, Y.P. Relations of the polar cap voltage to the geophysical activity. In Proceedings of the XXVI Annual Seminar "Physics of Auroral Phenomena", Apatity, Russia, 25-28 February 2003; pp. 59-61. Available online: http://pgia.ru:81/seminar/archive/2003/2_fields/feshchenko.pdf (accessed on 30 November 2020).

53. Lukianova, R.Y.; Christiansen, F. Modeling of the global distribution of ionospheric electric field based on realistic maps of field-aligned currents. J. Geophys. Res. Space Phys. 2006, 111, A03213. [CrossRef]

54. Kikuchi, T.; Ebihara, Y.; Hashimoto, K.; Kataoka, R.; Hori, T.; Watari, S.; Nishitani, N. Penetration of the convection and overshielding electric fields to the equatorial ionosphere during a quasiperiodic DP 2 geomagnetic fluctuation event. J. Geophys. Res. Space Phys. 2010, 115, A05209. [CrossRef]

55. Vorobjev, V.G.; Yagodkina, O.I. Auroral precipitation dynamics during strong magnetic storms. Geomagn. Aeron. 2007, 47, 185-192. [CrossRef]

56. Prölss, G.W. Ionospheric F-region Storms: Unsolved Problems. In Characterising the Ionosphere; RTO: Neuilly-sur-Seine, France; pp. 1-20. Available online: https:/www.sto.nato.int/publications/STO \% 20Meeting\%20Proceedings/RTO-MP-IST-056/MP-IST-056-10.pdf (accessed on 30 November 2020).

57. Foster, J.C.; Coster, A.J.; Erickson, P.J.; Holt, J.M.; Lind, F.D.; Rideout, W.; McCready, M.; van Eyken, A.; Barnes, R.J.; Greenwald, R.A.; et al. Multiradar observations of the polar tongue of ionization. J. Geophys. Res. Space Phys. 2005, 110, A09S31. [CrossRef]

58. Rodger, A.S.; Wrenn, G.L.; Rishbeth, H. Geomagnetic Storms in the Antarctic F-region. II. Physical Interpretation. J. Atmos. Terr. Phys. 1989, 51, 851-866. [CrossRef]

59. Wrenn, G.L.; Rodger, A.S.; Rishbeth, H. Geomagnetic storms in the Antarctic F-region. I. Diurnal and seasonal patterns for main phase effects. J. Atmos. Terr. Phys. 1987, 49, 901-913. [CrossRef]

60. Titheridge, J.E.; Buonsanto, M.J. A Comparison of Northern and Southern Hemisphere TEC storm behaviour. J. Atmos. Terrest. Phys. 1988, 50, 763-780. [CrossRef]

61. Yasyukevich, Y.V.; Yasyukevich, A.S.; Ratovsky, K.G.; Klimenko, M.V.; Klimenko, V.V.; Chirik, N.V. Winter anomaly in NmF2 and TEC: When and where it can occur. J. Space Weather Space Clim. 2018, 8, A45. [CrossRef]

62. Ercha, A.; Ridley, A.J.; Zhang, D.; Xiao, Z. Analyzing the hemispheric asymmetry in the thermospheric density response to geomagnetic storms. J. Geophys. Res. Space Phys. 2012, 117, A08317. [CrossRef] 
63. Burešová, D.; Laštovička, J. Pre-storm enhancements of foF2 above Europe. Adv. Space Res. 2007, 39, 1298-1303. [CrossRef]

64. Mikhailov, A.V.; Depueva, A.H.; Depuev, V.H. Daytime F2-layer negative storm effect: What is the difference between storm-induced and Q-disturbance events? Ann. Geophys. 2007, 25, 1531-1541. [CrossRef]

65. Mikhailov, A.V.; Perrone, L. Pre-storm NmF2 enhancements at mid latitudes: Delusion or reality? Ann. Geophys. 2009, 27, 1321-1330. [CrossRef]

66. Liu, L.; Wan, W.; Zhang, M.-L.; Zhao, B.; Ning, B. Prestorm enhancements in NmF2 and total electron content at low latitudes. J. Geophys. Res. Space Phys. 2008, 113, A02311. [CrossRef]

Publisher's Note: MDPI stays neutral with regard to jurisdictional claims in published maps and institutional affiliations.

(C) 2020 by the authors. Licensee MDPI, Basel, Switzerland. This article is an open access article distributed under the terms and conditions of the Creative Commons Attribution (CC BY) license (http://creativecommons.org/licenses/by/4.0/). 